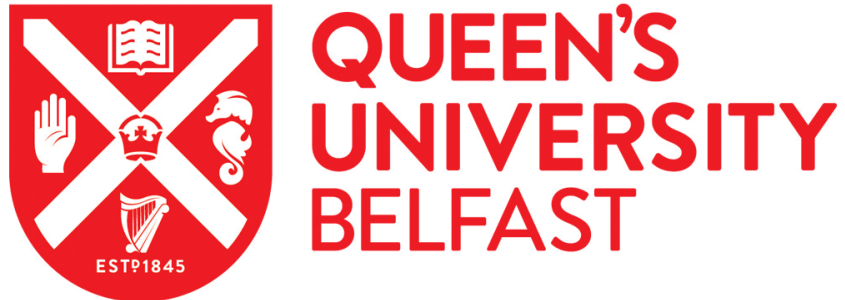

\section{Finding revelation in anthropology: Alexander Winchell, William Robertson Smith and the heretical imperative}

Livingstone, D. N. (2015). Finding revelation in anthropology: Alexander Winchell, William Robertson Smith and the heretical imperative. British Journal for the History of Science, 48(3), 435-454.

https://doi.org/10.1017/S0007087415000035

\section{Published in:}

British Journal for the History of Science

\section{Document Version:}

Peer reviewed version

Queen's University Belfast - Research Portal:

Link to publication record in Queen's University Belfast Research Portal

Publisher rights

(c) British Society for the History of Science 2015.

\section{General rights}

Copyright for the publications made accessible via the Queen's University Belfast Research Portal is retained by the author(s) and / or other copyright owners and it is a condition of accessing these publications that users recognise and abide by the legal requirements associated with these rights.

Take down policy

The Research Portal is Queen's institutional repository that provides access to Queen's research output. Every effort has been made to ensure that content in the Research Portal does not infringe any person's rights, or applicable UK laws. If you discover content in the Research Portal that you believe breaches copyright or violates any law, please contact openaccess@qub.ac.uk. 


\title{
Finding REVELATION IN ANTHROPOLOGY: \\ Alexander Winchell, William Robertson Smith, and the Heretical Imperative
}

\section{David N. Livingstone*}

\begin{abstract}
Anthropological inquiry has often been considered an agent of intellectual secularization. Not least is this so in the sphere of religion, where anthropological accounts have often been taken to represent the triumph of naturalism. This metanarrative however fails to recognise that naturalistic explanations could sometimes be espoused for religious purposes and in defence of confessional creeds. This essay examines two late nineteenth-century figures - Alexander Winchell in the United States, and William Robertson Smith in Britain - who found in anthropological analysis resources to bolster rather than undermine faith. In both cases these individuals found themselves on the receiving end of ecclesiastical censure and were dismissed from their positions at church-governed institutions. But their motivation was to vindicate divine revelation, in Winchell's case from the physical anthropology of human origins and in Smith's from the cultural anthropology of Semitic ritual.
\end{abstract}




\section{FINDING REVELATION IN ANTHROPOLOGY: Alexander Winchell, William Robertson Smith, and the Heretical Imperative}

As the ecclesiastical equivalent of blood sports, heresy hunting in the nineteenth century attracted a large following. Two cases, one on each side of the Atlantic, gripped public imaginations in the spring of 1878. Newspaper articles recounted their fate; the individuals concerned were dismissed from their academic posts; and both later found themselves hanging side-by-side in Andrew Dickson White's gallery of scientific martyrdom. On June 16 that year, the Nashville Daily American announced to its readers that a charge of "Heresy" at Vanderbilt' had just been brought against one of the university's professors and it allowed the 'heretic' space to explain himself in a piece entitled 'Science Gagged in Nashville'. 'The summary dismissal of the geologist Alexander Winchell (1824-1891) from his chair made headline news as the story spread like wildfire and attracted the editorialising pens of the Chattanooga Commercial, the Knoxville Chronicle, the Memphis Appeal and the Nashville Banner. ${ }^{2}$ Two or three weeks earlier, on May 28, four thousand miles away, the Aberdeen Weekly Journal updated its readers, in an article entitled 'The Aberdeen Heresy Case', on the latest twist of events in the libel suit currently before the Free Church of Scotland. Its final shot expressed the paper's disgruntlement at the likely irresolution of the outcome. It seemed that the Free Assembly would do nothing more than dismiss 'the clever, learned, and conceited young Professor from its bar, with some graceful and discreet new version of the old verdict "Not guilty; but don't do it again"." ${ }^{3}$ Whereas Winchell's execution was short, if not sweet, it would take a further three years before William Robertson Smith (1846-1894) eventually succumbed to the messy hewing of his denomination's legislative axe. But the outcome was the same. In May 1881 he was removed from his chair in Aberdeen on the grounds that it was no longer 'safe or advantageous for the Church that Professor Smith should continue to teach in one of her colleges'.

As a seemingly appropriate act of remembrance, Andrew Dickson White memorialised the demise of these respective chair-holders in a paragraph designed to counter any thought that Catholicism was more guilty than Protestantism of muzzling free inquiry:

Nothing is more unjust than to cast especial blame for all this resistance to science upon the Roman Church. The Protestant Church, though rarely able to be so severe, 
has been more blameworthy. The persecution of Galileo and his compeers by the older Church was mainly at the beginning of the seventeenth century; the persecution of Robertson Smith, and Winchell ... by various Protestant authorities, was near the end of the nineteenth century. ${ }^{5}$

The stigma of heresy may well have clung to Winchell and Smith, not least as they were widely exhibited as proponents of free thought untrammelled by a crippling confessionalism. But there is every reason to think that their espousal of anthropological perspectives sprang from deep-seated religious convictions. In different ways their concern was to show how subjecting traditional dogmas to scientific scrutiny could secure rather than sabotage Christian theology. This means that the adoption of naturalistic explanations of anthropological phenomena cannot be taken to mean that its practitioners automatically rejected the idea that God had revealed himself in history and that the Christian scriptures bore witness to his self-disclosure. ${ }^{6}$ Winchell and Smith thus serve my purposes in two ways. First, they act as fulcrum points for inspecting something of how naturalistic explanations, carefully circumscribed, could be put to work as an ally of faith. Second, they disclose how such tactics manifested themselves in projects pivotal to Victorian anthropology - the physical anthropology of human origins and the cultural anthropology of religious systems.

On both sides of the Atlantic, of course, nineteenth-century anthropological inquiry was widely regarded as subversive of the idea that scripture bore witness to divine revelation. In the United States, it has been suggested, 'the first real triumph of science' lay in anthropology, with its 'formulation of polygenetic theories of human origin'. According to Brown, the 'repudiation of the biblical chronology' was crucial to these endeavours - endeavours which contributed in a major way to the 'establishment, institutionalization and authority of American scientific work'. Josiah Nott and George Gliddon, for example, both prominent figures in the American School of Ethnology, were renowned for their anticlericalism and for castigating their opponents as 'advocates of murky theology and benighted superstition'. Delighting in what they called 'parson skinning', they hungrily fell upon every scrap of evidence they could find to undermine the traditional biblical doctrine of human unity through common descent from Adam. ${ }^{8} \mathrm{~A}$ passionate rejection of any theological justification for human unity was integral to Nott and Gliddon's repudiation of abolitionism and their belief in ineradicable black inferiority. Thus it is not surprising that castigating the biblical narrative was fundamental 
to their anthropological project. As Nott observed in 1848: 'Astronomy and geology, so long kept down by bigotry and ignorance, have triumphed, and the day is at hand when the natural history of man will burst the trammels which have so long held it captive ... My main object, therefore, in this volume, is to cut loose the natural history of mankind from the Bible'. 'Thereby, as Stanton notes, he firmly located anthropological investigations of human origins at the heart of 'the warfare which had long raged between science and theology'. ${ }^{10}$ Nott evidently enjoyed any fuss he was able to incite. His attack on the authenticity of the Pentateuch was intended to 'stir up hell in the Christians' and he rejoiced that 'some of the "godly" had "never slept" since they learned of his crusade. ${ }^{11}$ If anything Gliddon was yet more outrageous, castigating clergymen as 'skunks' and throwing himself with gusto into the polygenists' favourite pursuit: incessantly 'hammering at the biblical chronology'. ${ }^{12}$ With champions like this it is entirely understandable that members of the American School of Anthropology, as it came to be called, were widely regarded as 'passionate rejecters of Revelation'. ${ }^{13}$ Alongside their dedication to chattel slavery, the 'bond' which linked these figures was 'anticlericalism and antibiblicism'. ${ }^{14}$ As Abraham Coles quipped at the time in an extended critique of Nott and Gliddon's ethnological writings: 'To be a good reasoner it is necessary to be an infidel and a believer in slavery. ${ }^{15}$

In Europe, anthropological enterprises were no less increasingly associated with a denial of divine revelation in history and, a fortiori, scripture. In large measure, as the anthropologist stewart Guthrie notes, anthropological accounts of religion were 'secular and naturalistic', explaining 'religions as products of human culture and human nature, not as manifestations of anything transcendental, supernatural, or otherwise sui generis ${ }^{16}$ In France, for example, many late-nineteenth century anthropologists involved themselves in atheist campaigns of one sort or another. Paul Broca, according to the historian-philosopher Jennifer Hecht, 'was committed to rational explanation and the questioning of biblical truth', and used polygenism as a tool to counter Catholic theological anthropology and to foster 'a coherent scientific-atheist movement that lasted into the following century'. Darwin's 'vigorously antireligious' translator, the materialist Clémence Royer, was convinced that the use of natural scientific methods necessitated a head-on collision with religious belief. ${ }^{17}$ Taken in the round members of the Société d'Anthropologie (which included Royer) were committed to de-Christianising the Republic by installing the new scientific study of the human race in the place hitherto occupied by theological authority. 
In Britain this same antipathy to revelation relied heavily on versions of cultural evolutionism that are often regarded as the 'perspective with which anthropology started life'. ${ }^{18}$ The writings of figures such as Edward B. Tylor, James G. Frazer and Henry S. Maine dominated the anthropological horizon and collectively promoted the Comtean vision that 'monotheistic Christianity, though advanced as a religion, is only one stage on man's progress towards reason'. ${ }^{19}$ Overall, the historian of anthropology Henrika Kuklick judges, Victorian anthropology's collective 'attitude to religion was hostile. Anthropologists intended to repudiate Christianity'; in their day, as contributors to A.C. Haddon's memorial tribute announced, 'to be an anthropologist was generally considered equivalent to being an agnostic and free-thinker'. ${ }^{20}$

Tylor, often dubbed the father of anthropology in Europe, coupled an evolutionary account of religious faith together with the idea of cultural survivals from earlier ages, in order to explain why theological beliefs could persist in the absence of truthful cognitive content. Animated by strongly anti-Catholic sentiments, his anthropological writings helped fuel the image of inherent warfare between science and religion. ${ }^{21}$ Recalling Tylor's Quaker background, the intellectual historian John Burrow tellingly observed:

Theology was Tylor's particular concern, and he turned to it with the air of one about to cleanse the temple of the Lord, ominously remarking: 'It is with a sense of attempting an investigation which bears very closely upon the current theology of our own day, that I have set myself to examine systematically, among the lower races, the development of animism'. ${ }^{22}$

George Stocking concurs with Burrow, insisting that the logical thrust of Tylor's Primitive Culture was 'clearly to reduce Christianity' to the 'category of 'mythology'.' 'Rather than God having created man in His image', he adds, Tylor's judgment was that 'man had, through evolutionary time, created God in his'. ${ }^{23}$ As for Frazer, 'even more anti-Christian than Tylor' according to the historian of religion Ivan Strenski, his magnum opus, The Golden Bough, advanced 'a theory of the evolution of religion that sought to discredit the privileged, revealed status of Christianity'. ${ }^{24}$

While differing in particulars, the work of the Victorian anthropologists overall conveyed a strong sense that the enterprise's practitioners, as Edmund Leach put it, were of 'agnostic rationalist persuasion'. ${ }^{25}$ In similar vein, Edward E. Evans-Pritchard, reflecting on his own later professional experience as an anthropologist, observed in his 
Aquinas Lecture for 1959: 'Almost all the leading anthropologists of my own generation would, I believe, hold that religious faith is total illusion ... Religion is superstition to be explained by anthropologists, and not something an anthropologist, or indeed any rational person, could himself believe in'. ${ }^{26}$ Religious belief was thus variously explained or perhaps better, explained away - as a mechanism for fostering social solidarity and promoting community harmony, as mere wishful thinking to cope with crippling fears, or as a primitive means of explaining the universe that at best anticipated real science.

The adoption of naturalistic methods of inquiry as the 'distinctive mark of an anthropological study of religion' has thus routinely been seen as a strategy to undermine any idea that scripture bore witness to divine revelation. ${ }^{27}$ What this conventional reading tends to eclipse, however, are the ways in which the naturalistic methods of anthropological science could be used to bolster rather than demolish belief in divine revelation, and thereby to rescue it from agnostic reductionism of one stripe or another. The two individuals I have chosen to examine self-consciously set out to defend the belief that God had revealed himself, in one way or another, in scripture and history even though their respective ecclesiastical communities shunned their efforts and condemned their efforts as heretical.

Winchell had been appointed to the position of professor of geology and zoology at the newly-formed University of Vanderbilt in 1875, having previously occupied posts at the University of Michigan and Syracuse University. Here he sought to find ways of keeping his scientific and religious convictions in conceptual tandem. But his efforts were not welcomed by the Vanderbilt board of trustees, not least when he adopted the findings of prehistoric anthropology. Smith took up the chair of Hebrew at the Aberdeen Free Church College in 1870 and found in German higher criticism a valuable tool in making sense of the Old Testament. He also applied insights from conjectural prehistory and the anthropology of religion to the Hebrew Bible claiming that the findings of these sciences could be of theological benefit in interpreting the biblical documents.

Winchell and Smith, of course, were located in very different spaces which shaped, in significantly different ways, their theological, anthropological and scientific preoccupations. ${ }^{28}$ In Winchell's situation, in the heart of the American South where matters of ethnic relations and postbellum reconstruction loomed large, the tension between science and religion manifested itself most conspicuously in the arena of race history. Winchell was certain that the scientific investigations of the anthropologists into human origins and religious systems could help purge creeds and dogmas 'supposed to 
be inculcated by texts of revelation'. In so doing he was sure that 'revelation' would remain standing and that the 'religious system' would be rendered 'invincible to the assaults of its enemies' as much as to the 'suicidal daggers of its friends'. ${ }^{29}$ Smith, by contrast, found himself at the eye of a gathering storm over the introduction of the new biblical criticism into Britain. While he was convinced that it could aid theology in significant ways, most of his fellow churchmen considered biblical criticism to be a deeply suspicious enterprise. As part of this project he turned to the methods of historical anthropology. His extraordinarily innovative use of anthropological methods, however, led him in a radically different direction from the likes of Tylor and Frazer. Certainly he no longer espoused the traditional understanding of scripture as an infallible text, a collection of inerrant propositions. But as Mary Douglas insists: 'Robertson Smith never wavered in his faith in the Bible as a record of specific, supernatural Revelation'. ${ }^{30}$

Whatever the differences between Winchell and Smith, my aim in this essay is to supplement scholarship that troubles the assumption that naturalistic science necessarily entailed a repudiation of divine agency by redrawing attention to ways in which naturalistic methods could fit with metaphysical convictions about how God was believed to act in the natural world. ${ }^{31}$

\section{Alexander Winchell, Human Origins and the Peyrèrean Shadow}

When the Methodist-governed University of Vanderbilt in Tennessee eventually secured the services of Alexander Winchell (1824-1891) for several months a year in 1876, it had managed to win for the newly-born institution one of America's leading men of science. By the time he arrived, Winchell - a prominent Methodist - was already renowned as an authority on science and religion, as well as for his technical work on petrology and mineralogy. ${ }^{32}$ Twice Director of the Michigan Geological Survey, Winchell's expertise was wide-ranging, encompassing physics and engineering as well as geology, zoology, and botany - all of which he had taught at various times between 1853 and 1873 at the University of Michigan. Prior to arriving at Vanderbilt, Winchell had occupied the position of first chancellor of Syracuse University, and following his dismissal from Vanderbilt he returned to Michigan to concentrate on geology and palaeontology.

Winchell's downfall has been attributed to different causes. ${ }^{33}$ His espousal of evolution is one. Andrew Dickson White certainly took that view, announcing that he was driven forth for his views which centred in the Darwinian theory'. ${ }^{34}$ Undoubtedly Winchell did increasingly adopt evolution. In 1877, for example, he opened his 
Reconciliation of Science and Religion with the observation that in its pages the reader would 'detect indications of a growing faith' in 'the derivative origin of species' along the lines of Edward Drinker Cope's Neo-Lamarckism. ${ }^{35}$ On the Vanderbilt faculty there were those who abominated evolution. It was a pet peeve of the Dean, Thomas Summers, whom Winchell regarded as one of the 'old bigots' whose 'medieval influence' had lingered longer than it should. ${ }^{36}$ 'Evolution!' Winchell snapped. 'This is the bugbear so big and dark that nothing else could be heard or read by Dr Summers whenever I employed tongue or pen, ${ }^{37}$ For his part, Summers pointedly recorded in his dairy that a Sunday afternoon lecture by Winchell had made him 'quite unwell': 'He thinks the nebular theory and evolution are not incompatible with the Bible. I cannot reconcile them'. 38

There were other factors too. The appearance in 1878 of a set of essays by Winchell entitled Adamites and Preadamites, which argued that the earth had been peopled long before the biblical Adam, sent shock waves through the Southern Methodist connexion. ${ }^{39}$ Later Winchell developed these 50 or so pages into a book ten times the length. ${ }^{40}$ Its ugly racial rhetoric is only too conspicuous, even if typical of the brisk Southern trade in works of anthropology, comparative anatomy and archaeology. ${ }^{41}$ On superficial inspection, the whole document smelled of the polygenist anthropology being promoted by the Nott-Gliddon-Morton brigade. And that surely rubbed the Wesleyan fraternity the wrong way, violating the Methodist dedication to the unity of the human race. ${ }^{42}$ Summers declared that it was because his 'development of evolution and polygenism became so pronounced' that the University had to fire him $^{43}$ - a diagnostic phrasing that was picked up by the Nashville American. ${ }^{44}$ In fact that judgment was quite mistaken, for Winchell explicitly nailed his colours to the monogenist mast by declaring: "I have not affirmed ... that mankind, one in moral nature, are not one in origin; since I believe the blood of the first human stock flows in the veins of every living human being' ${ }^{45}$ For all that, his use of anthropological data generated by polygenetic anthropologists such as Morton, Nott and Gliddon fuelled the flames of suspicion.

There were other cross-currents too. Winchell's proposals concerning an extensive pre-adamic history of human groups - particularly the black races - raised troubling anxieties over whether these races lay beyond the scope of redemption: about what the Adamic fall from grace and original sin might mean in the new anthropological cosmos; and what the implications might be for a denomination putting strenuous efforts into church outreach to the black community. ${ }^{46}$ Rev Samuel Keneer Cox, for example, editor 
of the Episcopal Methodist, feared that Winchell's strategy for reconciling science with scripture 'totally alienates the African race from the blessings of the New and Everlasting Covenant'. The St Louis Christian Advocate, meanwhile, worried that it would undermine the denomination's ministry among members of the black population. Winchell worked hard to rebut slurs such as these. ${ }^{47}$

The fact that Winchell advertised the anthropological wares of the seventeenth century arch-heretic, Isaac La Peyrère, hardly helped either. According to the historian of philosophy Richard Popkin, La Peyrère 'was regarded as perhaps the greatest heretic of the age'. ${ }^{48}$ Peyrère's polygenism, he judged, was the 'real spectre haunting Western thought ... the most fundamental challenge to the Judaeo-Christian tradition to arise from the "new science" and the "new philosophy". ${ }^{49}$ As for Winchell, he thought Peyrère 'a victim of the intolerance of the times' whose insights were 'far in advance of his age'; later Winchell berated Peyrère's adversaries as 'the bond slaves of dogma'. ${ }^{50}$ In the American South, Peyrère's pre-adamism was well known to the likes of Nott and Gliddon, and no sooner had Winchell recruited him to his cause than the loathsome alliance with these modern infidels was spotted by reviewers.

Winchell's viciously racial anthropology fell foul of Methodist sensibilities of course, not least because some believed his conception of the black races placed them beyond the scheme of redemption. But it is no less clear that his turn to natural science explanations was also deeply troublesome. In the aftermath of the fracas, the October 1878 meeting of the Tennessee Conference of the Methodist Episcopal Church, South, declared that 'scientific atheism' had lately been spotted stalking the halls of academia and that its advocates were busily engaged in deluding 'the unthinking mass'. It was proud to report, however, that 'our university alone has had the courage to lay its young but vigorous hand upon the mane of untamed Speculation and say, "We will have no more of this". ${ }^{51}$ Summers had already said as much and more. Back in July he had congratulated Vanderbilt on steadfastly resisting 'atheistic, materialistic, anti-Church' forces and reminded his readers that good Methodists did not want their children educated in an atmosphere of 'genteel infidelity'. ${ }^{52}$ The Wesleyan Christian Advocate concurred, informing its readers that Winchell's 'pernicious speculations', if left unchecked, would 'directly contribute to sceptical habits of mind among the students'. ${ }^{53}$

The savour of speculative naturalism that many felt attached to Winchell's science doubtless arose on account of guilt by association with secular champions of evolutionary biology and polygenist anthropology. But it also stemmed from certain of 
his methodological pronouncements. Winchell was a committed theist, yet he was persuaded that the conventional distinction between primary and secondary causes was altogether unhelpful in thinking about scientific explanation. Because he was convinced of the ubiquity of natural law, he preferred to 'regard Supreme Intelligence as acting without intervention' in the 'evolution of life's beginnings' - a stance he supported by calling on the testimony of Darwin and Huxley. ${ }^{54}$ Though he was certain that 'divine immanence' did 'not conflict with the doctrine of law' he was fully aware that turning to the reign of law could sound like atheism. And so he quoted his fellow-Methodist Draper to the effect that it was 'a more noble view of the government of this world to impute its order to a penetrating, primitive wisdom, which could foresee consequences through a future eternity, and provide for them in the original plan, at the outset, than to invoke the perpetual intervention of an ever-acting, spiritual agency. ${ }^{55}$

Far from practising atheistic science, Winchell was sure that his scientific enthusiasms were fully compatible with his theological confession. In turning to natural science, Winchell believed he was defending, not destabilising, the integrity of divine revelation and of the Bible as witness to it. To begin with, he was sure that the 'Hebrew people had not attained to that degree of secular knowledge, and intellectual culture, and aesthetic refinement, which enabled their inspired writers to leave a record which, in all its details of style, should commend itself to the highest refinement the race was destined to attain'. This meant that the ancient Hebrews 'were unable to divest themselves, at times, of those very anthropomorphic conceptions which disfigure the mythologies of the Greeks and other ancient nations'. The implication was plain. It was the task of modern exegetes 'to penetrate beneath the anthropomorphic garb of the sacred teachings, and discover there the spiritual Being of purity and beneficence whose attributes, in other portions of our Scriptures, are so adequately and so eloquently described.$^{56}$ Properly prosecuted, Winchell believed, scientific inquiry could liberate the biblical record from charges of incoherence and contradiction and coax timeless meaning out of ancient shadows.

In his controversial Adamites and Preadamites Winchell elaborated upon this point. Because 'the inspired writers have sometimes plunged into the midst of the profound and mysterious facts of science', Winchell began, 'why not, then, summon all our knowledge to the task of evoking the meaning of the text?'. 'I maintain against the narrow and pernicious dogma that the Bible is sufficient everywhere to interpret itself,' he went on, arguing instead that 'it was ordained to be interpreted under the concentrated light of all the learning which has been created by a God-given intelligence in man'. This was 
particularly so with the anthropological sciences: 'we are at this day in possession of many collateral lines of evidence to place by the side of old scriptural interpretation. We can summon ethnology, archaeology and anthropology to bear witness'. By bringing the findings of these human sciences to bear on the Hebrew Bible, its interpretation would be freed from the 'dialectic skill which characterized the scholastic theology' as well as 'the dicta of councils and ecclesiastics'. On the particular question of the dispersal of the human species across the face of the earth, dogmatic proclamations about the repopulation of the world after Noah's flood had to surrender to a hermeneutic grounded in anthropological revelations. 'Whether the world has been populated by people who spread from Ararat forty-two centuries ago, or even from Mesopotamia fifty-nine centuries ago,' he maintained, 'is a question of fact, to be investigated strictly on the basis of scientific evidence..$^{57}$

Among the gifts that anthropological breakthroughs could bring to biblical revelation, then, was the clarification of texts that had too long remained locked up in the hermeneutic prison of traditional exegesis. Nowhere was this more pointedly relevant than in the doctrine of the unity of the human race, grounded in universal descent from Adam and Eve. The traditional reading of the Genesis chronology, Winchell contended, violated the fundamental principle of human consanguinity for the simple reason that if 'human beings have existed but 6,000 years, then the different races had separate beginnings, as Agassiz long since maintained'. This was because the available timescale was massively inadequate for humanity's ethnic differentiation and geographical diffusion to have taken place. Fortunately, anthropological investigations had shown how monogenism could be rescued from subversion by traditionalist creationism. As he went on: '... if all human beings are descended from one stock, then the starting point was more than 6,000 years back: as Huxley and the evolutionists generally maintain; and the Duke of Argyll and other anti-evolutionists equally maintain'. Winchell was marshalling anthropological science in the service of Methodist monogenism. Acknowledging the existence of a much earlier common stock from which the Adamic family had descended, Winchell believed, had theological consequences dear to the heart of every good Wesleyan. For it was in keeping with St Paul's doctrine announced in the book of the Acts of the Apostles (17: 26) that God had 'made of one blood all nations' of the earth. As Winchell explained: 
This view recognizes the unity of man; the possession of 'one blood' by all the races, one moral and intellectual nature, and one destiny; it recognizes Adam as the progenitor of the nations which form the theme of biblical history; it explains sundry biblical allusions and implications - for instance, the wife found by Cain in the land of Nod; Cain's fear of violence from others when condemned to the life of a 'fugitive and a vagabond'; ... it validates the biblical chronology. ${ }^{58}$

The extended sweep of time that palaeo-anthropology delivered thus resolved several long-standing conundrums. Racial diversity had been simply inexplicable on the standard reading. 'The time from Adam (according to accepted chronology) to the date at which we know the negro type had been fully established,' for example, was 'vastly too brief for so great a divergence, in view of the imperceptible amount of divergence since such date'. Explaining the advanced state of cultures 'celebrated for agriculture, mechanics, and music' that were portrayed in the periods between Adam, Noah and the days of Peleg was 'greatly accommodated and relieved by a larger allowance of time'. For it was just extremely 'difficult to believe' that the degree of linguistic diversity, the extent of urban society, and the range of nationalities depicted could have 'come into existence from one family in the space of 131 years' - the period of time Winchell computed using patriarchal chronology from Noah's flood to the birth of Peleg's son. ${ }^{59}$ Scientific evidence for the continuing existence of human cultures predating Adam resolved at a stroke such tensions.

Winchell's adventures in historical anthropology had convinced him that it 'was many thousand years ago that the first being appeared which could be called a man ... That first of all men did not make his advent in Asia, nor in Europe, nor in America. He appeared either in Africa or in a continental land which stretched from Madagascar to the East Indies'. That these creatures were fully human Winchell had no doubt, for they had 'implanted' within them 'the divine spark of intelligence', 'listened to the voice of conscience and felt the claims of duty'. Generations passed until the 'time arrived, at length, when, under the law of progressive development, a grade had been reached nearly on a level with that of modern civilized man, in respect to native capacities. Now appeared the founder of the Adamic family. His home was in central Asia' ${ }^{60}$

While this scenario might trouble the old guard, Winchell had no doubts about the theological benefits such a scheme delivered: 
If it traverses old opinions, we need not mourn. New truths are better than old errors ... The loss of a belief, like the death of a friend, seems a bereavement; but a false belief is only an enemy in a friend's cloak. It is only truth which is divine; and if we embrace an error, we shall not find it ratified in the oracles of divine truth. ... If our creed embodies a dogma which enunciates what is really a conclusion, true or false, based on scientific evidence - that is, evidence brought to light by observation and research - that may be exscinded as an excrescence. All such subjects are to be settled by scientific investigation - not by councils of the church. Ecclesiastical faith has had a very sorry experience in the attempt to sanctify popular opinions. ${ }^{61}$

More than two centuries earlier, in 1657, Winchell's predecessor, Isaac La Peyrère, had been stigmatised as a heretic for his pre-adamite theory and forced to recant before Pope Alexander VII. While Peyrère was often paraded as the quintessential sceptic, there is reason to suggest, as Grafton does, that Peyrère too believed that 'by making Genesis a more reasonable text, he would make it more convincing. ${ }^{62}$ Winchell certainly thought him fundamentally orthodox - a right-headed believer mustering the insights of contemporary science to preserve the integrity of Pentateuchal chronology. This was Winchell's passion too. And if this was heresy, then heresy was an obligation. As things turned out, Winchell stood in Peyrère's shadow in more ways than one.

\section{William Robertson Smith, Textual Evolution and Mimetic Cannibalism}

William Robertson Smith is widely regarded as having made foundational contributions to cultural anthropology, the sociology of religion, and biblical criticism. ${ }^{63}$ Testimonials abound. Freud told his readers that it was impossible to convey 'any notion of the lucidity or ... argumentative force' of the 'many-sided ... keen and free-thinking' Smith. Elsewhere Freud simply described him as a 'man of genius ${ }^{64}$ Durkheim celebrated the remarkable 'revolution' that Smith had accomplished in his theory of sacrifice. ${ }^{65}$ And Mary Douglas condensed his influence in the acerbic quip: 'Durkheim took up [Smith's] central thesis and set comparative religion in fruitful lines. Frazer took up his incidental minor thesis, and sent comparative religion into a blind alley'. ${ }^{66}$

In 1876, when the first stirrings of heresy Angst over Smith were beginning to be heard on the floor of the Free Church Assembly in Scotland, these accolades were still in the distant future. Had they been available to Smith's adversaries, of course, such tributes 
would only have confirmed them in their opinion that the young professor kept altogether bad company. Applause from the likes of Freud and Durkheim would simply have attested to the infidel cast of Smith's mind. What had catapulted Smith into the limelight was an article on the 'Bible' he had just published in the ninth edition of the Encyclopaedia Britannica. ${ }^{67}$ In it, he introduced the thinking of the continental higher critics, arguing that three main sources ran through significant parts of the Old Testament - a Levitico-Elohistic strand using the term 'Elohim' for God; a Jehovistic narrative in which God, termed YHWY, appears as an anthropomorphic figure; and the work of an unknown author specially interested in the ancestors of the northern kingdom. Central to his analysis was the fundamental distinction Smith drew between the priestly and prophetic traditions in ancient Israel, the former ordinarily finding the 'progressive ideas' of the latter 'distasteful to their natural conservatism and aristocratic instincts'. What governed his entire approach to the reconstruction of the compositional history of the Hebrew scriptures, was the idea of what he called 'the gradual development of the religion of revelation'. Smith resorted to Darwinian-sounding rhetoric in depicting the evolutionary path of Hebrew spirituality by speaking of the 'struggle' between different religious impulses and the survival of those elements which proved themselves 'fitter than any other belief to supply all the religious needs of the people'. ${ }^{68}$ All of this rubbed entirely the wrong way the traditional conception of the Bible as propositional revelation by direct divine communication, operating beyond the laws of nature. Smith dismissed that 'mere mechanical theory', and asserted that the experience of divine disclosure did not annihilate - or even suspend - a single element of the prophet's personality or mental processes. The prophet was no 'mere lyre struck by the plectrum of the Spirit'. ${ }^{69}$ Such claims disturbed conservative elements in the Free Church to the core and charges were soon brought against Smith for the 'dangerous and unsettling tendency' of his thought. $^{70}$

With its labyrinthine twists and turns, the case dragged on for several years. It was initially dismissed in May 1880 albeit with an 'admonishment' to the professor that 'in the time to come you will carefully guard against all approach to the same line and the same tone of statement. ${ }^{71}$ Smith willingly acquiesced. But no sooner had the verdict been announced than another earthquake tremor was registered on the heresy-hunters' Richter scale. A second case was underway.

The very day on which the 1880 Assembly concluded its business, the new issue of the Journal of Philology appeared. It carried an article by Smith; ominously, it dealt with 
animal worship in the Old Testament. The mainsprings of this latest offering dated back to Smith's reading of the Scottish lawyer and parliamentary draughtsman John Ferguson McLennan (1827-1881) who, in 1869-70, had published a three-part essay on animal and plant worship for the Fortnightly Review..$^{72}$ Here he advanced an account of totemism according to which a plant or animal is adopted by a tribal group as an emblem of the clan and plays a fundamental role in the social functioning of primitive religion through being the object of worship. ${ }^{73}$ This theory built on McLennan's earlier 1865 Primitive Marriage, which portrayed early humans as savages living in a promiscuous horde. Here McLennan painted a picture of the origins of civilization as both matriarchal and polyandric, and ultimately rooted in the unintended consequences of female infanticide. ${ }^{74}$ These narratives were grounded in McLennan's social-evolutionary conception of progress from savagery to civilisation. They relied heavily on the idea of 'survivals ${ }^{75}-\mathrm{a}$ mode of explanation that made much of the persistence of functionless rituals lingering from earlier phases of human history such as ceremonial customs associated with bridekidnapping. In the transition from savagery to civilisation, McLennan located tribal groups bound together by totemism and he used their totemic names as a means of identifying clans engaging in exogamy.

Smith applied this way of thinking to the Old Testament, exploring such themes as animal gods, totem tribes, exogamy, matriarchal kinship and levirate marriage in the Hebrew Bible ${ }^{76}$. He quickly came to the conclusion that his findings were 'remarkably confirmatory of Mr McLennan's theory - a theory framed almost absolutely without reference to the Semitic races'. Smith began by reviewing what he called the 'pure polytheism' of ancient Arabia so as to provide historical context for his treatment of early Israel where he argued that the 'spiritual religion' had to struggle against 'the relics of ancestral heathenism'. Among the evidences for this struggle, he believed, was a wide range of tribes and families with animal names which had totemic significance. King David, for example, apparently belonged to the serpent stock. Coupling such findings with scrutiny of the Levitical laws concerning incest and food, Smith was convinced that 'superstition of the totem kind had still a hold on the Israelites in the last years of the independence of the kingdom of Judah'. The perception of ancient Hebrew religion as 'constitutionally monotheistic' with 'a lofty character from which spiritual ideas were easily developed' was thus far mistaken. To the contrary, his conclusion was that 'the superstitions with which the spiritual religion had to contend were not one whit less degrading than those of the most savage nations'. ${ }^{77}$ 
If Smith hoped that this venture would lie buried on dusty shelves, he was mistaken, for Rev. George Macaulay was on the look-out. On Thursday 29 July 1880, Macaulay informed readers of The Scotsman of his resolve to press the Church authorities 'to issue an edict peremptorily prohibiting Professor Smith from the exercise of his functions as minister and professor in the Church'. The denomination, he insisted, was in grave peril, and its traditional standards had to be protected from Smith's 'pernicious views' ${ }^{78}$ Smith's account of ancient Semitic marriage codes and animal worship were described by Macaulay as 'so gross and so fitted to pollute the moral sentiments of the community' that they could not be aired beyond 'the closed doors of any court of this Church'. ${ }^{99}$ These allegations proved to be the opening shots in the final phase of the five-year-long campaign to unseat Smith. The guillotine fell in the early hours of May 25, 1881 and Smith's tenure of his chair was terminated. ${ }^{80}$

Smith's theories about the authorship, dating and historicity of various biblical books were deeply troubling, but so too was the odour of rationalistic speculation that he seemed to exude. In March 1878, The Scotsman reported the views of a certain Mr Arthur that the 'tendency' of Smith's outlook could best be judged by the current condition of the Protestant Church in Germany; it 'was thoroughly leavened with infidelity and rationalism' ${ }^{81}$ Shortly after Smith's initial acquittal, Dr Kennedy, minister of the Free Church in Dingwall, complained that it was his 'display of rationalism' that had 'decoyed' the Church's 'leading men off the ground' on which they should have stood firm. ${ }^{82} \mathrm{Dr}$ Horatius Bonar, later moderator of the Free Church General Assembly, similarly attacked Smith's love of 'conjectural criticism'. ${ }^{83}$ William Binney, Professor at the Aberdeen Free Church College, classed people like Smith who doubted the Mosaic authorship of Deuteronomy as 'infidels' ${ }^{84}$ And in a lengthy rebuttal, the Irish Presbyterian theologian Robert Watts sniped: 'One cannot choose between such a theory and scepticism for the simple reason that there is no difference between the two things ... Whether it come from the pen of a Kuenen, or a Wellhausen, or a Smith, it is still the same faith-subverting theory'. ${ }^{85}$

Dismissal from his Aberdeen Chair did nothing to curb Smith's fertile mind and from his new position at the University of Cambridge he issued ever more influential insights. His 1887 Burnett Lectures, later published as The Religion of the Semites, and described as 'one of the founding texts of modern anthropology', are illustrative. ${ }^{86}$ The entire edifice was erected on an evolutionary scaffolding. To Smith, traditional practices had evolved slowly over the course of centuries, and for that reason bore the stamp of 'habits of 
thought characteristic of very diverse stages of man's intellectual and moral development'. Perhaps reflecting the lessons on physical geography that he had received from his father, ${ }^{87}$ Smith was sure that ritual forms disclosed historical sequencing analogous to geological strata:

The record of the religious thought of mankind, as it is embodied in religious institutions, resembles the geological record of the history of the earth's crust; the new and the old are preserved side by side, or rather layer upon layer. The classification of ritual formations in their proper sequence is the first step towards their explanation, and that explanation itself must take the form, not of a speculative theory, but of a rational life-history. ${ }^{88}$

This evolutionary methodology perfectly suited Smith's project, for he was certain that to elucidate the true nature of primitive religion, practice must take precedence over dogma, and the customary segregation of religious observance from ordinary life must be broken down. Because 'antique religions had for the most part no creed', their study 'must begin, not with myth, but with ritual and traditional usage'. ${ }^{89}$ The fundamental character of institutions and practices meant that, for Smith, the basic unit of analysis was community practice, not individual belief. Individuals did not decide on their religion in primeval times; rather religion came to them as a fundamental constituent of the social obligations laid upon them by virtue of their location in family and clan.

Having thus laid down the foundations on which his analysis would be constructed, Smith turned his thoughts to the evolution of ritual in the Hebrew cult. Drawing again on the inspiration of McLennan, he underscored the central role of sacrifice in the production and reproduction of a primal sense of social belonging. The ritual slaying and devouring of a totemic victim, normally regarded as taboo, were taken by Smith as an exercise in sacramental communion between the human and divine worlds and as the means of maintaining a primal sense of clan cohesion and tribal harmony. ${ }^{90}$ Sacrificial observance was thus central to ancient tribal life. ' $[\mathrm{P}]$ articipation in the flesh of a sacrosanct victim, and the solemn mystery of its death', Smith explained, was the only way in which 'the sacred cement [could] be procured which creates or keeps alive a living bond of union between the worshippers and their god'. ${ }^{91}$

But there was even more to Smith's theory than this. Primordial sacramental feasting, he was convinced, was not confined to animal sacrifice. Cases of human ceremonial 
slaying and ritualistic cannibalism were to be found, and Smith was sure that their progressive demise was not on account of any natural human revulsion against consuming human flesh. 'What seems to us to be natural loathing' he observed, 'often turns out ... to be based on a religious taboo, and to have its origin not in feelings of contemptuous disgust but of reverential dread'. ${ }^{92}$ Of course as these ritual systems evolved, their exterior features were progressively stripped of such repulsive undertakings. The 'primitive crudity of the ceremonial was modified and the meaning of the act is therefore more or less disguised,' Smith explained. Its genesis was obscured, but its deep structure endured. It crystallised in later Hebrew ceremonial regulations about ritual uncleanness, forbidden foods and the like, revealing that certain rites 'preserved with great accuracy the features of a sacrificial ritual of extreme antiquity'.'

All of this fell foul of the axiomatic assumptions of traditional Scottish Calvinists, not least when Smith's observations gestured towards eucharist. This was especially so when he spoke of how 'the various aspects in which atoning rites presented themselves to ancient worshippers have supplied a variety of religious images which passed into Christianity, and still have currency'. Critical theological terms such as 'redemption, substitution, purification, atoning blood, the garment of righteousness' could thus all be traced back 'to antique ritual'. ${ }^{94}$ Plainly the entire architecture of the Judaeo-Christian system of salvation, though stripped of its primeval debauchery, was associated in some deep way with mimetic cannibalism.

The application of the methods of natural science to the biblical record and the religious life of the ancient Semites had brought Smith a long way. Indeed the degree to which he embraced these modes of analysis, according to the biblical scholar John Rogerson, 'has sometimes been misunderstood to the point of thinking that Smith modified or gave up his own Christian beliefs, ${ }^{95}$ For radical though his conclusions might seem, there is every reason to suppose that Smith's methodology was forged in the crucible of his theological credo. As Rogerson continues: 'it cannot be stressed strongly enough that Smith was not a compromiser, or someone who accepted the results of criticism reluctantly, and accommodated them to an increasingly watered-down version of Christianity. On the contrary, Smith was an enthusiast for biblical criticism because he believed that it freed the Old Testament from fetters that made it a closed book'. ${ }^{96}$ Even if this assessment is perhaps overly sanguine about the degree to which Smith's theology remained constant, there is no doubt that in adopting naturalistic criticism Smith was engaged in a project to vindicate rather than invalidate divine revelation. As Riesen 
insists, Smith sought 'to advance faith not in spite of but by means of the critical method'. ${ }^{97}$

Perhaps Smith's clearest explanation of his methodological machinery came in the series of lectures on The Old Testament in the Jewish Church he delivered in the winter of 1880 to an estimated average audience of eighteen hundred in Edinburgh and Glasgow. What animated this entire enterprise was his confidence that an evolutionary perspective could shore up what he believed to be the essence of Judaeo-Christian truth and so Smith began by insisting that the 'great value of historical criticism is that it makes the Old Testament more real to us'. To be sure, there was 'a widespread uneasy suspicion that this history cannot bear to be tested like other ancient histories'. But that was a misplaced fear, for the simple reason that the 'old method of explaining difficulties and reconciling apparent contradictions would no longer be tolerated in dealing with other books'..$^{8}$ The whole point of his endeavours, by contrast, was to convince hearers that biblical criticism, 'a branch of historical science', using naturalistic methods, was both 'legitimate and necessary'. For to Smith, it was only by applying its empirical procedures that readers could come to 'distinguish between the accidental and the essential, the human conjectures and the divine truth'. The task was to mobilise the historical sciences to piece together the true chronology of the Hebrew canon and to 'separate' out the different 'instrumentalities' and 'elements' that had come together in its construction. To achieve this end he emphasised that the prophetic writers 'were not mere impassive channels through whose lips or pens God poured forth abstract doctrine' and were certainly 'not exempt from the necessary laws and limitations of human speech'.9

A couple of years later Smith put these principles to work in his analysis of The Prophets of Israel. Here he underscored the fertility of evolutionary modes of explanation. The record of revelation, he insisted, could only be understood organically - 'by tracing its growth'. 'A mechanism', he explained, 'is studied by taking it to pieces, an organism must be studied by watching its development from the simplicity of the germ to the final complexity of the finished structure' ${ }^{100}$ This meant that 'revelation follows the laws of historical progress' just as 'a law of continuity runs through the succession of physical phenomena'; plainly there were 'laws in the moral world as well as in the material cosmos'. And so the insights of natural scientific explanation should be embraced not feared, proclaimed not concealed: 'In the interests of religion, as well as of sound knowledge, it is of the highest importance that everything which scholarship has to tell about the Old and New Testaments should be plainly and fully set before the intelligent 
Bible readers. The timidity which shrinks from this frankness, lest the untrained student may make a wrong use of the knowledge put in his hands, is wholly out of place in Protestant Churches'. ${ }^{101}$

Seen in this light the anonymous 'Scotulus' - a Free Review critic - failed to perceive the theological mainsprings of Smith's textual and anthropological endeavours when he complained, at the time of Smith's death, that 'he pursued the methods of rationalistic literary analysis while holding to the faith of Bibliolatrous superstition'. ${ }^{102}$ It is something similar with the religious studies scholar Robert Segal who, while appreciating his pioneering contributions, questions Smith's status as 'the first modern sociologist of religion' since he restricted sociological analysis to ancient religion, allegedly because he wanted to preserve his own theological commitments. As he concludes, Smith's 'theological approach to higher religion sought to keep the door closed to a wholly secular account of modern religion'. ${ }^{103}$ What these diagnoses underplay is the extent to which Smith's anthropological and sociological innovations were propelled by theological convictions.

For of course William Robertson Smith never set out to be a modern 'sociologist' or 'anthropologist'. He was a theologian from beginning to end - but a theologian embarked on the task of showing how scientific explanations could sustain genuine faith rather than subvert it, and enable authentic spirituality to be detached from mere cultic ceremonial. Smith's inquiries into the genealogy of Semitic religion were neither 'a neutral investigation nor an exercise in comparative religion for the sake of undermining religious truth claims'. ${ }^{104}$ Rather they were designed to excavate what he called 'the first germs of eternal truths' that lay buried beneath the materialist surface of external ritual forms. ${ }^{105}$ For Smith's passion was to use the methods of scientific criticism to 'show to the world the Divine Revelation of God in the Old Testament'. ${ }^{106}$

\section{Conclusion}

Both Alexander Winchell and William Robertson Smith display something of the ways in which naturalistic explanations prominent in the new sciences of physical and cultural anthropology could be marshalled in the service of religion in general, and in divine revelation in particular. This does not imply of course that their modes of operation were identical. They were located in different places where different concerns troubled their local constituencies. Amongst Winchell's Methodists in the American South matters of race relations and the mobilisation of anthropology to query traditional monogenism 
loomed large. In Scotland, Smith's redrafting of the understanding of scripture to accommodate German higher criticism and to recast it as a record of revelation was widely thought to conflict with the Westminster Confession of Faith. The revelations that they found in anthropology, too, were of different kinds. Insofar as the 'Baconian Compromise', as Moore terms it, remained relevant in late nineteenth century anthropological endeavour, Winchell might be seen as promoting its insistence that scriptural revelation had to be read in the light of God's revelation in nature. ${ }^{107}$ Smith, by contrast, seems to have abandoned that path by conceiving of scripture more as a chronicle of evolving spiritual consciousness than merely propositional revelation. Yet they were united in their conviction that scientific insights could liberate the kernel of real faith from the husk of traditionalist hermeneutics and thereby demonstrate that naturalistic anthropological explanations could be of real theological benefit.

Winchell's refusal of the conventional distinction between natural and supernatural agency complicates the received understanding of the essence of naturalistic science, while his adoption of archaeo-anthropological findings to preserve the integrity of the Mosaic chronicle hints at a counter-narrative to the standard reading of naturalistic anthropology as inherently hostile to biblical chronology. As for Smith, his endeavours remind us that the emergence of the anthropology of religion as a scientific pursuit was itself facilitated in no small measure by the advent of historical-critical studies of the Bible which submitted the Hebrew scriptures to the same kind of 'naturalistic scrutiny as any piece of literature'. ${ }^{108}$ Despite their best efforts, of course, both men suffered the fate of heretics by being dismissed from their positions at church-governed institutions. In both cases they had found in the revelations of anthropology resources that they believed would vindicate the revelations attested to in scripture. In large measure their espousal of the findings of natural science was motivated by theological concerns to retain faith not to overturn it, to support the scriptural record not to destabilise it. Their different constituencies did not agree. To the guardians of orthodoxy, they were allies of rationalism and purveyors of heresy. But if that was the settled judgment of their denominational paymasters, then to Winchell and Smith heresy was orthodoxy's most urgent imperative.

* School of Geography, Archaeology and Palaeoecology, Queen's University Belfast, Belfast, BT7 1NN, Northern Ireland. Email: d.livingstone@qub.ac.uk 


\section{Acknowledgements}

I am most grateful to Diarmid Finnegan and Peter Harrison for their insightful comments on an earlier draft of this paper, to Joe Webster for enlightening conversations about anthropology and religion, to Tim Larsen for a number of valuable leads, and to two anonymous readers whose observations have helped me further clarify my arguments.

1 “"Heresy” at Vanderbilt', Nashville Daily American 16 June, 1878; Alexander Winchell, 'Science gagged in Nashville', Nashville Daily American 16 June, 1878.

${ }^{2}$ Mary Engel, 'A chapter in the history of academic freedom: the case of Alexander Winchell', History of Education Journal (1959) 10, pp. 73-80.

3 'The Aberdeen heresy case', Aberdeen Weekly Journal 28 May, 1878.

${ }^{4}$ John Sutherland Black and George Chrystal, The Life of William Robertson Smith London: Adam \& Charles Black, 1912, p. 426.

${ }^{5}$ Andrew Dickson White, $A$ History of the Warfare of Science with Theology in Christendom Vol. 1, New York: Appleton, 1896, p. 168.

${ }^{6}$ Matthew Stanley examines the adoption of naturalist methods in Victorian science by theistic scientists in 'The uniformity of natural laws in Victorian Britain: naturalism, theism, and scientific practice', Zygon, (2011) 46, pp. 536-560

${ }^{7}$ H. Ricardo Brown, Until Darwin, Science, Human V ariety and the Origins of Race, London: Pickering \& Chatto, 2010, pp. 59, 60.

${ }^{8}$ Thomas F. Gossett, Race: The History of an Idea in America, New York: Schocken Books, 1965 , p. 64.

${ }^{9}$ Josiah C. Nott, Two Lectures on the Connection between the Biblical and Physical History of Man, Delivered by Invitation, from the Chair of Political Economy, Etc, of the Lonisiana University, in December, 1848, New York: Bartlett and Welford, 1849, p. 7.

${ }^{10}$ William Stanton, The Leopard's Spots: Scientific Attitudes Toward Race in America 1815-1859 Chicago: University of Chicago Press, 1960, p. 119.

${ }^{11}$ Stanton, op. cit. (10), p. 122.

${ }^{12}$ Stanton, op. cit. (10), pp. 122, 196.

${ }^{13}$ Abraham Coles, A Critique on Nott and Gliddon's Ethnological Works, Burlington, N.J.: Office of the Medical and Surgical Reporter, 1857, p. 9.

${ }^{14}$ Stanton, op. cit. (10), p. 193.

${ }^{15}$ Coles, Critique on Nott and Gliddon's Ethnological Works, p. 6.

${ }^{16}$ Stewart E. Guthrie, 'Anthropological theories of religion', in Michael Martin (ed.), The Cambridge Companion to Atheism, Cambridge: Cambridge University Press, 2006, pp. 283290, on p. 283.

${ }^{17}$ Jennifer Michael Hecht, The End of the Soul: Scientific Modernity, Atheism, and Anthropology in France, New york: Columbia University Press, 2003, pp. 56, 76, 65.

${ }^{18}$ Robert Carneiro, Evolutionism in Cultural Anthropology, Boulder Colo.: Westview Press, 2003, p. 287.

${ }^{19}$ Roger Smith, The Fontana History of the Human Sciences, London: Fontana Press, 1997, p. 479.

${ }^{20}$ Henrika Kuklick, The Savage Within: The Social History of British Anthropology, 1885-1945, Cambridge: Cambridge University Press, 1991, p. 79.

${ }^{21}$ See Timothy Larsen, 'E.B. Tylor, religion and anthropology', British Journal for the History of Science, (2013) 46, pp. 467-485. Recently Keel has argued that despite his rejection of Christianity Tylor actually perpetuated, unbeknownst to himself, elements derived from a 
Christian theology of the natural world. See Terence D. Keel, 'Religion, polygenism and the early science of human origins', History of the Human Sciences (2013) 26, pp. 3-32.

${ }^{22}$ John W. Burrow Evolution and Society: A Study in Victorian Social Theory, Cambridge: Cambridge University Press, 1966, p. 256. The extract from Tylor comes from E. B. Tylor, Primitive Culture: Researches Into the Development of Mythology, Philosophy, Religion, Art, and Custom, London: John Murray, 1871, vol 1, p. 21.

${ }^{23}$ George W. Stocking Jr., Victorian Anthropology, New York: The Free Press, 1987, p. 195. See also Reginald Horsman, Josiab Nott of Mobile: Southerner, Physician, and Racial Theorist, Baton Rouge: Louisiana State University Press, 1987).

${ }^{24}$ Ivan Strenski, 'The spiritual dimension', in Henrika Kuklick (ed), A New History of Anthropology, Oxford: Blackwell, 2008, pp. 113-127, on p. 119.

${ }^{25}$ Edmund Leach, 'The anthropology of religion: British and French schools', in Ninian Smart, John Clayton, Steven Katz and Patrick Sherry (eds), Nineteenth Century Religious Thought in the West, Cambridge: Cambridge University Press, 1985, vol. 3, pp. 215-262, on p. 217.

${ }^{26}$ E.E. Evans-Pritchard, 'Religion and the anthropologists', in Essays in Social Anthropology, London: Faber and Faber, 1962, pp. 29-45, on p. 36.

${ }^{27}$ Strenski, op. cit. (24), p.113.

${ }^{28}$ The role of place in shaping scientific enterprises in David N. Livingstone, Putting Science in its Place, Chicago: University of Chicago Press, 2003.

${ }^{29}$ Alexander Winchell, Reconciliation of Science and Religion, New York: Harper, 1877, pp. 31, 28,31

${ }^{30}$ Mary Douglas, Purity and Danger: An Analysis of Concept of Pollution and Taboo, London: Routledge, 2002, orig. 1966, p. 19.

${ }^{31}$ See the forthcoming collection of essays edited by Peter Harrison. I am grateful to Professor Harrison for sharing with me a draft of his introduction. See also Gowan Dawson and Bernard Lightman (eds), Victorian Scientific Naturalism: Community, Identity, Continuity, Chicago: University of Chicago Press, 2014.

${ }^{32}$ F. Garvin Davenport, 'Alexander Winchell: Michigan scientist and educator', Michigan History (1951) 35, pp. 185-201.

${ }^{33}$ Leonard Alberstadt, 'Alexander Winchell's preadamites - a case for dismissal from Vanderbilt University', Earth Sciences History (1994) 13, pp. 997-112; Mary Engel, 'A chapter in the history of academic freedom: the case of Alexander Winchell', History of Education Journal (1959) 10, pp. 73-80; Maura Jane Farrelly, "God is the author of both': science, religion, and the intellectualization of American Methodism', Church History (2008) 77, pp. 659-687; Mark David Wood, 'Debating science and religion: towards a comparative geography of public controversy, 1874-1895', PhD thesis, Queen's University Belfast, 2011.

${ }^{34}$ White, op. cit. (5), vol. 1, 84.

${ }^{35}$ Alexander Winchell, op. cit. (29),New York: Harper, 1877, p. v. On Cope's NeoLamarckism, see Peter J. Bowler, The Eclipse of Darwinism: Anti-Darwinian Theory of Evolution in the Decades Around 1900, Baltimore: Johns Hopkins University Press, 1983.

${ }^{36}$ Recorded in his 1878 diary, cited in Wood, op. cit. (33), pp. 121, 124.

${ }^{37}$ Winchell, op. cit. (1).

${ }^{38}$ Oscar Penn Fitzgerald, Dr Summers: A Life-Study, Nashville: Southern Methodist Publishing House, 1885, pp. 288, 289.

${ }^{39}$ Alexander Winchell, Adamites and Preadamites: A Popular Discussion Concerning the Remote Representatives of the Human Species and their Relation to the Biblical Adam, Syracuse: John T. Roberts, 1878. 
${ }^{40}$ Alexander Winchell, Preadamites; or a Demonstration of the Existence of Men before Adam together with a Study of their Condition, Antiquity, Racial Affinities, and Progressive Dispersion over the Earth, Chicago: S.C. Griggs, 1880.

${ }^{41}$ See David N. Livingstone, Adam's Ancestors: Race, Religion and the Politics of Human Origins, Baltimore: Johns Hopkins University Press, 2008.

${ }^{42}$ See Reginald F. Hildebrand, The Times were Strange and Stirring: Methodist Preachers and the Crisis of Emancipation, Durham, N.C.: Duke University Press, 1995. The Methodist commitment to human unity, however, did not 'alter the basic pattern of "an inferior and subordinate relation" of blacks in the church'. William B. Gravely, 'The social, political and religious significance of the formation of the colored Methodist Episcopal Church (1870)', Methodist History (1979) 18, pp. 3-25, on p. 8.

${ }^{43}$ T.O. Summers, 'Vanderbilt University and the critics', Nashville Christian Advocate 13 July 1878.

${ }^{44}$ Cited in Alberstadt, op. cit. (33), p. 110.

${ }^{45}$ Winchell, op. cit. (40), p. v.

${ }^{46}$ See the discussion in Livingstone, op. cit. (41), chapter 6.

${ }^{47}$ Quoted in Wood, op. cit. (33), p. 144.

${ }^{48}$ Richard Popkin, Isaac La Peyrère (1596-1676). His Life, Work and Influence, Leiden: Brill, 1987, p. 1.

${ }^{49}$ Richard Popkin, 'Pre-adamism in $19^{\text {th }}$ century American thought: 'Speculative biology' and racism', Philosophia (1978) 8, pp. 205-239, on p. 206.

${ }^{50}$ Winchell, op. cit. (39), p. 6; Winchell, op. cit. (40), p. 457.

${ }^{51}$ Quoted in White, History of the Warfare, Vol. 1, p. 315. See also Farrelly, op. cit. (33).

${ }^{52}$ Summers, 'Vanderbilt University'. See also Charles A. Israel, Before Scopes: Evangelicalism, Education, and Evolution in Tennessee, 1870-1925, Athens, GA: University of Georgia Press, 2004, p. 135.

53 'The Vanderbilt and Dr. Winchell', Wesleyan Christian Advocate 17 August, 1878, quoted in Wood, op. cit. (33), p. 146.

${ }^{54}$ Winchell, op. cit. (29), p. 144.

${ }^{55}$ Winchell, op. cit. (29), p. 132. The passage, with minor differences, comes from John William Draper, $A$ History of the Intellectual Development of Europe, New York: Harper Brothers, 1864, p. 74.

${ }^{56}$ Winchell, op. cit. (29), p. 204.

${ }^{57}$ Winchell, op. cit. (39), pp. 4, 7.

${ }^{58}$ Winchell, op. cit. (39), p. 19, 20

${ }^{59}$ Winchell, op. cit. (39), pp. 47, 48, 49.

${ }^{60}$ Winchell, op. cit. (39), pp. 26-27.

${ }^{61}$ Winchell, op. cit. (39), p. 29.

${ }^{62}$ Anthony Grafton, New Worlds, Ancient Texts: The Power of Tradition and the Shock of Discovery, Cambridge, Mass: Harvard University Press, 1992, p. 211.

${ }^{63}$ Bernhard Maier, William Robertson Smith: His Life, His Work, His Times, Tübingen: Mohr Siebeck, 2009; Gillian M. Bediako, Primal Religion and the Bible: William Robertson Smith and bis Heritage, Sheffield: Sheffield Academic Press, 1997; T.O. Beidelman, W. Robertson Smith and the Sociological Study of Religion, Chicago: University of Chicago Press, 1974. A summary account of Smith's anthropological contributions is provided by George W. Stocking Jr., After Tylor: British Social Anthropology, 1888-1951, Madison: University of Wisconsin Press, 1995, pp. 63-81.

${ }^{64}$ Sigmund Freud, Totem and Taboo: Resemblances between the Psychic Lives of Savages and Neurotics, London: Routledge, 1919, pp. 220, 221; Sigmund Freud, An Autobiographical Study, New York: Norton, 1952, p. 76. 
${ }^{65}$ Émile Durkheim, The Elementary Forms of the Religious Life: A Study in Religious Sociology, London: Allen and Unwin, 1915, p. 336.

${ }^{66}$ Douglas, op. cit. (30), p. 19.

${ }^{67}$ The circumstances of the trial are discussed in Black and Chrystal, op. cit. (4); William Johnstone (ed), William Robertson Smith: Essays in Reassessment, Sheffield: Sheffield Academic Press, 1995.

${ }^{68}$ William Robertson Smith, 'Bible', Encyclopaedia Britannica, 1875, ninth edition, volume 3, p. 634.

${ }^{69}$ William Robertson Smith, 'Prophecy and personality: a fragment', (1868) in John Sutherland Black and George Chrystal (eds), Lectures and Essays of William Robertson Smith, London: Adam and Charles Black, 1912, pp. 97-108, on pp. 98, 97.

${ }^{70}$ Quoted in John Sutherland Black and George Chrystal, op. cit. (4), p. 209.

${ }^{71}$ Quoted in Black and Chrystal, op. cit. (4), p. 360.

${ }^{72}$ J.F. McLennan, 'The Worship of Animals and Plants', Fortnightly Review NS (1869) 4, pp. 407-427, 562-582; (1870), 7, pp. 194-216.

${ }^{3}$ See Adam Kuper, The Invention of Primitive Society: Transformations of an Illusion, London: Routledge, 1991, pp. 82-83; Robert Alun Jones, The Secret of the Totem: Religion and Society from McLennan to Freud, New York: Columbia Press, 2005.

${ }^{74}$ John F. McLennan, Primitive Marriage: An Inquiry into the Origins of the Form of Capture in Marriage Ceremonies, Edinburgh: A\&C Black, 1865.

${ }^{75}$ See Margaret Hodgen, 'The Doctrine of Survivals: The History of an Idea', American Anthropologist, (1931) 33, pp. 307-324; and Stocking, Victorian Anthropology.

${ }^{76}$ Levirate marriage refers to a Jewish law requiring a deceased man's brother, who died childless, to marry the widow.

${ }^{77}$ William Robertson Smith, 'Animal Worship and Animal Tribes among the Arabs and in the Old Testament', Journal of Philology (1880) 9, pp.75-100, on p. 78, 99, 100.

${ }^{78}$ Scotsman 29 July 1880 , p. 4.

${ }^{79}$ Cited in Black and Chrystal, op. cit. (4), pp. 381-382.

${ }^{80}$ Black and Chrystal, op. cit. (4), p. 438.

81 'The case of Professor Robertson Smith', Scotsman 15 March 1878.

82 'Rev. Dr. Kennedy, Dingwall, on Robertson Smith's Case', Scotsman 10 June 1880.

${ }^{83}$ Cited in Black and Chrystal, op. cit. (4), p. 418.

${ }^{84}$ 'Letters to the Editor. Professor Robertson Smith and the Rev. Dr Binnie', Scotsman 21 1880.

${ }^{85}$ Robert Watts, The Newer Criticism and the Analogy of the Faith: A Reply to Lectures by W. Robertson Smith, M.A., on the Old Testament in the Jewish Church, Edinburgh: T\&T Clark, 1882, pp. ix, x.

${ }^{86}$ Christopher Herbert, Culture and Anomie: Ethnographic Imagination in the Nineteenth Century, Chicago: University of Chicago Press, 1991, p. 56.

${ }^{87}$ See Bediako, op. cit. (63), p. 123.

${ }^{88}$ William Robertson Smith, Lectures on the Religion of the Semites, London: Black, 1889, p. 26.

${ }^{89}$ Smith, op. cit. (88), pp. 18, 20.

${ }^{90}$ Accounts of Smith's anthropology of sacrifice abound. See, for example, Margit Warburg, 'William Robertson Smith and the study of religion', Religion (1989) 19, pp. 41 61; Gordon Booth, 'The fruits of sacrifice: Sigmund Freud and William Robertson Smith', Expository Times (2002) 113, pp. 258-264; George Elder Davie, 'Scottish philosophy and Robertson Smith', in The Scottish Enligbtenment and Other Essays, Edinburgh: Polygon, 1991, pp. 101-145.

${ }^{91}$ Smith, op. cit. (88), p. 295. 
${ }^{92}$ William Robertson Smith, Kinship and Marriage in Early Arabia, London: Black, 1885, pp. 306-307.

${ }^{93}$ Smith, op. cit. (88), p. 277.

${ }^{94}$ Smith, op. cit. (88), p. 418.

${ }^{95} \mathrm{John}$ W. Rogerson, The Bible and Criticism in Victorian Britain: Profiles of F.D. Maurice and William Robertson Smith, Sheffield: Sheffield University Press, 1995, p. 71.

${ }^{96}$ John W. Rogerson, 'W.R. Smith's The Old Testament in the Jewish Church: its antecedents, its influence and its abiding value', in Johnstone (ed), William Robertson Smith, pp. 132 147, on p. 142.

${ }^{97}$ Richard Allen Riesen, Criticism and Faith in Late Victorian Scotland: A.B. Davidson, William Robertson Smith and George Adam Smith, Lantham: University Press of America, 1985, p. 117. In a more recent account which lays greater emphasis on the significance of ecclesiological problems than on critical questions, Kidd and Wallace stress that Robertson Smith and his defenders 'emphasized that biblical criticism, far from being crypto-Moderatism, was a continuation of Reformation principles and true Calvinism'. See Colin Kidd and Valerie Wallace, 'Biblical criticism and Scots Presbyterian dissent in the age of Robertson Smith', in Scott Mandelbrote and Michael Ledger-Lomas (eds), Dissent and the Bible in Britain, c. 1650-1950, Oxford: Oxford University Press, 2013, pp. 233-255, on p. 245.

${ }^{98}$ William Robertson Smith, The Old Testament in the Jewish Church, London: Black, 1895, second enlarged edition, $\mathrm{p}$. xi.

${ }^{99}$ Smith, op. cit. (98), pp. 1, 13, 13, 15.

${ }^{100}$ William Robertson Smith, The Prophets of Israel and their Place in History to the Close of the Eighth Century B.C., London: Black, new edition 1895 [orig. 1882], pp. 6-7.

${ }^{101}$ Smith, The Prophets of Israel, pp. 3, lii.

${ }^{102}$ Scotulus, 'Professor Robertson Smith: a problem', The Free Review (1894) May 1, $97-$ 107, on p. 98.

${ }^{103}$ Robert Segal, 'William Robertson Smith: sociologist or theologian?’, Religion 38 (2008): 9-24, on pp. 9, 24.

${ }^{104}$ Gillian M. Bediako, “To capture the modern universe of thought": Religion of the Semites as an attempt at a Christian comparative religion', in Johnstone, William Robertson Smith, pp. 118-130, on p. 126.

${ }^{105}$ William Robertson Smith, 'Sacrifice', Encyclopaedia 1886, ninth edition, vol. 21, p. 138. ${ }^{106}$ Quoted in Rogerson, op. cit. (95), p. 146.

${ }^{107}$ James R. Moore, 'Geologists and interpreters of Genesis in the nineteenth century', in David C. Lindberg and Ronald L. Numbers (eds), God and Nature: Historical Essays on the Encounter Christianity and Science, Berkeley: University of California Press, 1986, pp. 322350.

${ }^{108}$ Strenski, op. cit. (24), p. 115. 